JLJ 9 (1) (2020)
Joyful Learning Journal

\title{
KEEFEKTIFAN MODEL COURSE REVIEW HORAY BERBANTUAN MEDIA KONKRET TERHADAP HASIL BELAJAR IPA
}

\section{Bekti Widhi Astuti ${ }^{\bowtie}$, Desi Wulandari}

Jurusan Pendidikan Guru Sekolah Dasar, Fakultas Ilmu Pendidikan, Universitas Negeri Semarang, Indonesia

\begin{tabular}{|c|c|}
\hline Info Artikel & Abstrak \\
\hline $\begin{array}{l}\text { Sejarah Artikel: } \\
\text { Diterima Januari } \\
\mathbf{2 0 2 0} \\
\text { Disetujui Februari } \\
\mathbf{2 0 2 0} \\
\text { Dipublikasikan } \\
\text { Maret } 2020\end{array}$ & $\begin{array}{l}\text { Pelaksanaan pembelajaran IPA kelas V SDN Gugus Wolter Monginsidi dominan ceramah, diskusi, dan tanya } \\
\text { jawab. Model konvensional ini pelaksanaan pembelajarannya belum optimal menyebabkan hasil belajar IPA } \\
\text { rendah. Penelitian ini bertujuan untuk menguji keefektifan model pembelajaran kooperatif tipe Course Review Horay } \\
\text { berbantuan media konkret terhadap hasil belajar IPA siswa kelas V SDN Gugus Wolter Monginsidi Kabupaten } \\
\text { Kendal. Penelitian ini menggunakan pendekatan kuantitatif dengan jenis penelitian eksperimen. Desain penelitian } \\
\text { adalah Quasi Experimental dengan bentuk Nonequivalent Control Group Design. Sampel penelitian ini menggunakan } \\
\text { pengambilan teknik purposive sampling. Subjek penelitian ini adalah SDN } 1 \text { Sarirejo sebagai kelas eksperimen dan } \\
\text { SDN } 3 \text { Sarirejo sebagai kelas kontrol. Hasil uji t-test menunjukan bahwa thitung }>\text { tabel }(3,142>1,997) \text {, artinya hasil } \\
\text { belajar yang diperoleh kelas eksperimen lebih besar dibandingkan kelas kontrol. Hal ini didukung oleh hasil uji N- } \\
\text { Gain yaitu kelas eksperimen dengan kriteria sedang }(0,55) \text {, dan kelas kontrol berada pada kriteria rendah (0,29). } \\
\text { Berdasarkan hasil penelitian tersebut dapat disimpulkan bahwa model Course Review Horay berbantuan media } \\
\text { konkret lebih efektif diterapkan pada pembelajaran IPA siswa kelas V SDN Gugus Wolter Monginsidi } \\
\text { dibandingkan model konvensional serta bermanfaat untuk meningkatkan hasil belajar IPA. }\end{array}$ \\
\hline \multirow{2}{*}{$\begin{array}{l}\text { Keywords: } \\
\text { Effectiveness; } \\
\text { Course Review } \\
\text { Horay; Concrete } \\
\text { media; Learning } \\
\text { outcomes; Science; }\end{array}$} & Abstract \\
\hline & 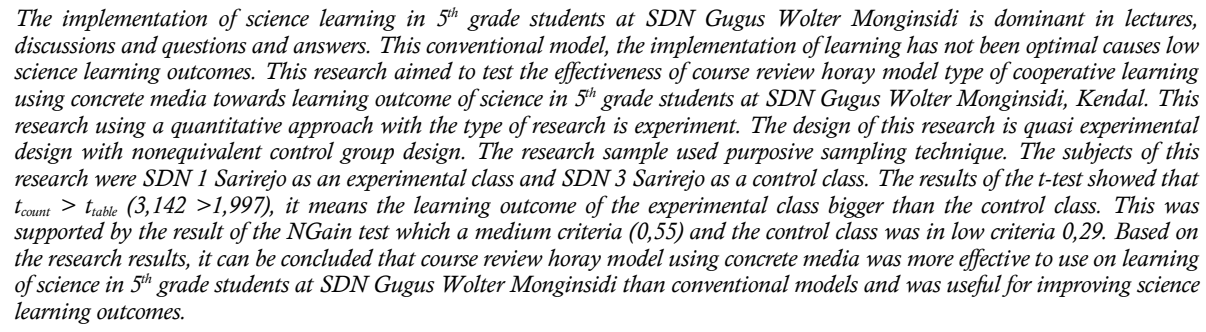 \\
\hline
\end{tabular}

(C) 2020 Universitas Negeri Semarang

\footnotetext{
Alamat korespondensi:

Kuripan Kidul RT 01 RW 04, Pekalongan, Jawa Tengah

E-mail: bektiwidhi@gmail.com
}

ISSN 2252-6366 


\section{PENDAHULUAN}

Perkembangan pendidikan membantu manusia dalam menjalani kehidupan. Pendidikan yang telah terbentuk untuk mencetak sumber daya manusia yang berkualitas meliputi aspek spiritual, afektif, kognitif, dan psikomotorik. Hal ini sesuai dengan tujuan bangsa Indonesia yang diperjelas pada isi pembukaan UUD 1945 yaitu mencerdaskan kehidupan bangsa. Pelaksanaan pendidikan di Indonesia yang semakin pesat, tentunya tak lepas dari dari peningkatan mutu pendidikan termasuk kurikulum.

Berdasarkan Peraturan Menteri Pendidikan Nasional No. 37 Tahun 2018, pada kurikululum 2013 terdapat muatan pelajaran Ilmu Pengetahuan Alam (IPA). IPA merupakan pengetahuan yang tersusun secara sistematis, berlaku universal dan berupa kumpulan hasil observasi maupun eksperimen (Carin dan Sund, 1993). Hal ini menandakan IPA belajar mengenai fenomena alam dan penguasaan pengetahuan berupa fakta, konsep, atau prinsip dalam proses penemuan. Kegiatan pembelajaran IPA di SD/MI masih didominasi oleh guru tentunya sangat berdampak pada hasil belajar siswa yang belum optimal. Pencapaian hasil belajar diukur melalui penilaian sesuai dengan permendikbud No. 23 tahun 2016 tentang Standar Penilaian Sekolah Dasar dan Menengah.

Studi internasional yang dilakukan oleh TIMSS (Trends in Mathematic and Science Study) tahun 2015 menunjukan Ilmu pengetahuan berada diperingkat 45 dari 48 negara dengan skor 397 Berdasarkan studi TIMSS tersebut, hasil belajar sains tergolong rendah sehingga perlu adanya solusi meningkatkan pemahaman dan nilai hasil belajar siswa.

Berdasarkan hasil observasi, wawancara, dan hasil belajar IPA menunjukan adanya permasalahan dalam proses pembelajaran diantaranya terdapat siswa kurang memperhatikan guru, dan cenderung pasif. Proses pengamatan yang telah dilakukan, guru menerapkan model yang dominan ceramah, diskusi, dan tanya jawab. Pembelajaran berpusat pada guru atau teacher centered. Diskusi dilakukan melalui tanya jawab. Selain itu, diskusi juga dilakukan dengan berkelompok, namun pembentukan kelompok masih berdasarkan tempat duduk sehingga belum mencapai sintak tertentu. Hal ini juga didukung oleh data hasil belajar IPA siswa kelas V di SDN Gugus Wolter Monginsidi yang masih belum mencapai KKM (Kriteria Ketuntasan Minimal). Terbukti siswa yang tuntas kurang dari $60 \%$ dari 140 siswa terdapat 73 siswa (52\%) belum mencapai KKM.

Berdasarkan data hasil belajar IPA yang belum optimal, maka perlu diterapkan model pembelajaran yang inovatif untuk meningkatkan hasil belajar yang dapat membuat siswa berpikir kritis, dan berperan aktif. Model pembelajaran dapat membantu siswa memperoleh informasi, gagasan, ketrampilan, nilai, cara berpikir, dan sarana dalam mengekspresikan diri (Joice \& Weil,
1996:7). Penerapan model yang dapat digunakan yaitu model kooperatif tipe Course Review Horay. Model course review horay adalah model pembelajaran yang mewujudkan suasana kelas yang menyenangkan dan menarik sebab setiap kelompok yang menjawab benar maka berteriak „Hore!!"e (Huda,2013:229). Model ini bercirikan pengujian pemahaman materi melalui kompetisi, pemberian penghargaan sehingga menumbuhkan kerjasama bersifat positif di antara siswa, menerima adanya setiap perbedaan, dan mengembangkan ketrampilan siswa. Pembelajaran dengan menggunakan bantuan media maka pembelajaran menjadi lebih bermakna. Arsyad (2014:4) berpendapat bahwa media merupakan alat yang dimanfaatkan untuk menyampaikan informasi. Penggunaan pemilihan media konkret pada proses pembelajaran, karena disesuaikan pada materi IPA yang berkaitan dengan fenomena alam yang ada disekitar lingkungan.

Penelitian yang mendukung penelitian ini adalah penelitian oleh Jake M. Laguador (2014) berjudul "Cooperative Learning Approach in an Outcomes-Based Enviroment". Pembelajaran studentcenter adalah pendekatan efektif untuk mencapai hasil belajar yang optimal. Pendekatan kooperatif mendorong berpartisipasi aktif, menjalin kerjasama, terjadi interaksi sosial dan pengalaman belajar yang lebih baik. Penelitian yang dilakukan oleh Meirza Nanda Faradita (2017) dengan judul "Pengaruh Model Pembelajaran Kooperatif Tipe Course Review Horay terhadap Motivasi Belajar Siswa Mata Pelajaran IPA di Sekolah Dasar". Hasil penelitian tersebut menunjukan bahwa terdapat perbedaan yang signifikan pada hasil belajar kelompok siswa yang menerapkan model Course Review Horay dan model konvensional.

Rumusan masalah penelitian ini adalah Bagaimana keefektifan model pembelajaran kooperatif tipe Course Review Horay berbantuan media konkret terhadap hasil belajar IPA siswa kelas V SDN Gugus Wolter Monginsidi dibandingkan dengan model pembelajaran konvensional? Tujuan penelitian ini adalah menguji keefektifan model pembelajaran kooperatif tipe course review horay berbantuan media konkret terhadap hasil belajar IPA siswa kelas V SDN Gugus Monginsidi dibandingkan dengan model pembelajaran konvensional.

\section{METODE PENELITIAN}

Pendekatan pada penelitian ini menggunakan kuantitatif dengan jenis penelitian eksperimen. Penelitian ini menggunakan Quasi Experimental Design dengan bentuk Nonequivalent Control Group Design (Sugiyono,2016:116). Populasi pada penelitian ini yaitu semua siswa kelas V di SDN Gugus Wolter Monginsidi Kabupaten Kendal. Teknik pengambilan sampel menggunakan teknik purposive sampling. Sampel peneltian ini yaitu SDN 1 Sarirejo sebagai kelas eksperimen, dan SDN 3 Sarirejo sebagai kelas kontrol. 
Instrumen yang digunakan adalah pretest dan posttest. Varibel yang digunakan pada penelitian ini yaitu model course review horay berbantuan media konkret sebagai varibel bebas (X) dan hasil belajar IPA sebagai variabel terikat (Y). Penelitian ini dilakukan sebanyak empat kali pertemuan di kelas eksperimen maupun kelas kontrol. Teknik pengumpulan data dalam penelitian ini menggunakan teknik tes dan teknik non tes berupa wawancara, observasi, dan dokumentasi. Teknik analisis data dalam penelitian ini terdiri atas analisis data awal meliputi uji normalitas, uji homogenitas, dan analisis data akhir meliputi uji normalitas, uji homogenitas, pengujian hipotesis (uji t-test), dan uji N-Gain.

\section{HASIL DAN PEMBAHASAN}

\section{Hasil Belajar Kognitif Siswa}

Hasil belajar kognitif pada penelitian ini berupa data nilai pretest dan posttest. Nilai pretest digunakan untuk mengukur kemampuan awal sebelum diberi perlakuan dan nilai posttest berfungsi untuk menarik kesimpulan hipotesis. Hasil pretest dan posttest kelas eksperimen dan kontrol dapat dilihat dalam tabel berikut.

Tabel 1 Hasil Belajar Pretest dan Posttest

\section{Posttest}

\section{Pretest}

Keterang

an
Eks

peri men

\begin{tabular}{clcccc}
\hline 1. & Jumlah & 38 & 30 & 38 & 30 \\
& Siswa & & & & 82,50 \\
2. & Rata-rata & 61,37 & 60,87 & 72,66 & \\
3. & Nilai & 80 & 83 & 93 & 97 \\
& Tertinggi & & & 40 & 50 \\
4. & $\begin{array}{l}\text { Nilai } \\
\text { Terendah }\end{array}$ & 30 & 40 & 40 & \\
\hline
\end{tabular}

Analisis Data Awal

\section{Uji Normalitas Data Pretes}

Uji normalitas digunakan untuk mengetahui data hasil belajar berdistribusi normal atau tidak. Penelitian ini dalam uji normalitas menggunakan uji Kolmogorov Smirnov dengan bantuan program komputer SPSS versi 22. Jika sig.>0,05 maka data berdistribusi normal, sedangkan jika sig<0,05 maka tidak berdistribusi normal.

Tabel 2 Uji Normalitas Nilai Pretest Siswa Kelas V

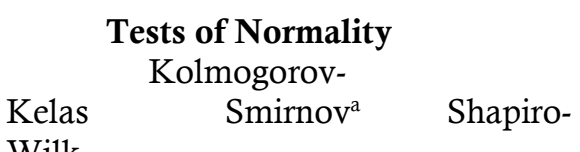

Statisticdf Sig. StatisticDf Sig.

$\begin{array}{lllll}\text { Hasil Nilai } & .106 & 30.200^{*} & .96130 .325\end{array}$

Nilai

\begin{tabular}{lllll} 
& .121 & 38.170 & .91238 .006 \\
Kontrol & & & \\
\hline
\end{tabular}

Berdasarkan tabel 2, Hasil perhitungan uji normalitas yaitu kelas kontrol sig. 0,170, dan kelas eksperimen dengan sig. 0,200. Kedua kelas tersebut memiliki nilai Sig. $>0,05$, sehingga $\mathrm{H}_{0}$ diterima dan $\mathrm{H}_{\mathrm{a}}$ ditolak artinya data berdistribusi normal.

\section{Uji Homogenitas Data Pretest}

Uji Homogenitas digunakan untuk mengetahui data pretest kelas eksperimen dan kelas kontrol memiliki varians data yang sama atau tidak. Pengujian homogenitas penelitian ini menggunakan uji ANOVA bantuan SPSS versi 22. Jika nilai Sig. $>0,05$ maka data memiliki varians sama. Apabila Sig. $<0,05$ maka data mempunyai varians tidak sama.

Tabel 3 Uji Homogenitas data pretest Siswa Kelas $\mathrm{V}$

Test of Homogeneity of Variances Pretest IPA

\begin{tabular}{rrrr}
\hline Levene Statistic & df1 & df2 & \multicolumn{1}{l}{ Sig. } \\
.719 & 1 & 66 & \\
\hline
\end{tabular}

Berdasarkan tabel 2, hasil uji homogenitas data pretest yaitu nilai signifikansi 0,399 (0,399 > $0,05)$ maka $\mathrm{H}_{0}$ diterima dan $\mathrm{H}_{a}$ ditolak artinya data memiliki varians yang sama atau homogen.

\section{Analisis Data Akhir Uji Normalitas Data Posttest}

Uji normalitas dalam penelitian ini menggunakan uji Kolmogorov Smirnov dengan bantuan program komputer SPSS versi 22 .

Tabel 4 Uji Normalitas Nilai Posttest Siswa Kelas $\mathrm{V}$

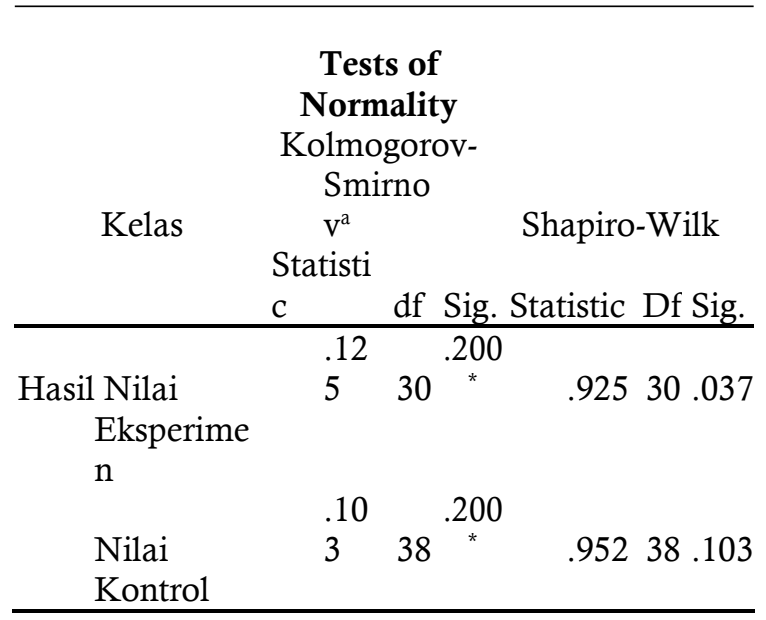

Berdasarkan tabel 4, Hasil perhitungan uji normalitas yaitu kelas kontrol sig. 0,200, dan kelas eksperimen dengan sig. 0,200. Kedua kelas tersebut memiliki nilai Sig. $>0,05$, sehingga $\mathrm{H}_{0}$ diterima dan $\mathrm{H}_{\mathrm{a}}$ ditolak artinya data berdistribusi normal. 


\section{Uji Homogenitas Data Posttest}

Pengujian homogen atau tidaknya pada data nilai posttest menggunakan uji ANOVA dengan bantuan program komputer SPSS versi 22 .

Tabel 5 Uji Homogenitas data prosttest Siswa Kelas $\mathrm{V}$

Test of Homogeneity of Variances Pretest IPA

\begin{tabular}{|c|c|c|}
\hline Levene Statistic & $\mathrm{df1}$ & Sig. \\
\hline .609 & 66 & .438 \\
\hline
\end{tabular}

Berdasarkan tabel 2, hasil uji homogenitas data pretest yaitu nilai signifikansi $0,438(0,438>$ $0,05)$ maka $\mathrm{H}_{0}$ diterima dan $\mathrm{H}_{a}$ ditolak artinya data memiliki varians yang sama atau homogen.

\section{Uji Hipotesis}

Uji hipotesis pada penelitian ini menggunakan uji Independent Sample Test berbantuan SPSS versi 22. Kriteria uji hipotesis yakni $\mathrm{t}_{\text {hitung }}>\mathrm{t}_{\text {tabel }}$ maka $\mathrm{H}_{0}$ ditolak dan $\mathrm{H}_{\mathrm{a}}$ diterima. Berikut hasil uji Independent Sample T-Test data nilai posttest :

Tabel 6 Hasil Uji Independent Sample T-Test

\begin{tabular}{|c|c|c|c|c|c|c|c|c|c|c|}
\hline & & \multicolumn{2}{|c|}{$\begin{array}{l}\text { Levene's Test } \\
\text { for Equality } \\
\text { of Variances }\end{array}$} & \multicolumn{7}{|c|}{ t-test for Equality of Means } \\
\hline & & \multirow[t]{2}{*}{$\mathrm{F}$} & \multirow[t]{2}{*}{ Sig. } & \multirow[t]{2}{*}{$\mathrm{T}$} & \multirow[t]{2}{*}{ Df } & \multirow{2}{*}{$\begin{array}{l}\text { Sig. } \\
(2 . \\
\text { tailed) }\end{array}$} & \multirow{2}{*}{$\begin{array}{l}\text { Mean } \\
\text { Diffe- } \\
\text { rence }\end{array}$} & \multirow{2}{*}{$\begin{array}{l}\text { Std. } \\
\text { Error } \\
\text { Diffe- } \\
\text { rence }\end{array}$} & \multicolumn{2}{|c|}{$\begin{array}{l}95 \% \\
\text { Confidence } \\
\text { Interval of the } \\
\text { Difference }\end{array}$} \\
\hline & & & & & & & & & $\begin{array}{c}\text { Lowe } \\
\mathrm{r}\end{array}$ & Uper \\
\hline & $\begin{array}{c}\text { Equal } \\
\text { variance } \\
s \\
\text { assumed }\end{array}$ & & & 3,142 & 66 & ,003 & 9,842 & 3,132 & 3,589 & $\frac{16,09}{5}$ \\
\hline \multirow[t]{2}{*}{ Nilai } & & ,609 & ,438 & & & & & & & \\
\hline & $\begin{array}{c}\text { Equal } \\
\text { variance } \\
\text { s not } \\
\text { assumed }\end{array}$ & & & 3,180 & $\begin{array}{c}64,72 \\
7\end{array}$ & ,002 & 9,842 & 3,095 & 3,661 & $\frac{16,02}{4}$ \\
\hline
\end{tabular}

Berdasarkan tabel 6, maka diperoleh hasil yang menunjukan bahwa $t_{\text {hitung }}>t_{\text {tabel }}(3,142>1,997)$, maka $\mathrm{H}_{0}$ ditolak dan $\mathrm{H}_{\mathrm{a}}$ diterima artinya pembelajaran dengan model $\mathrm{CRH}$ berbantuan media konkret lebih efektif daripada model pembelajaran konvensional terhadap hasil belajar siswa kelas V SDN Gugus Wolter Monginsidi.

\section{Uji N-Gain}

Uji N-Gain digunakan untuk mengetahui peningkatan rata-rata nilai pretest dan posttest kelas eskperimen dan kelas kontrol.

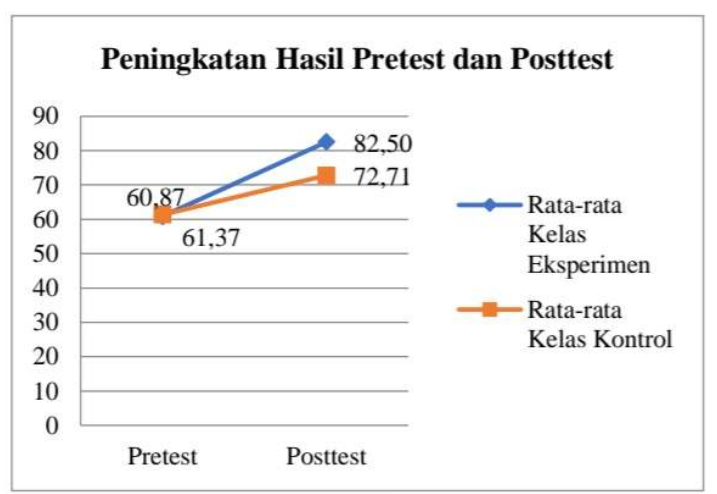

Diagaram 1 Peningkatan Rata-rata Hasil Belajar IPA Siswa Kelas V SDN Gugus Wolter Monginsidi

Berdasarkan Diagram 1, maka diperoleh bahwa kemampuan awal yang dimiliki siswa pada kelas kontrol dan kelas eksperimen hampir sama. Terbukti pada hasil rata-rata nilai siswa ketika pretest yang menunjukan kelas kontrol mendapatkan rata-rata sebesar 61,37 , dan kelas eksperimen sebesar 60,87 . Kemudian pada kelas eksperimen diberikan perlakuan menggunakan model Course Review Horay berbantuan media konkret hasil belajar yang diperoleh dalam muatan pelajaran IPA siswa kelas V lebih meningkat dibandingkan pada siswa dikelas kontrol.

Tabel 7 Hasil Perhitungan Uji N-Gain Kelas Kontrol dan Kelas Eksperimen

\begin{tabular}{ccccc}
\hline \multirow{4}{*}{ Nilai rata-rata } & & \\
Kelas & & & Nilai & \\
& Pretest & Posttest & n-gain & \\
& & & & \\
\hline Kontrol & 61,37 & 72,66 & 0,29 & Rendah \\
Eksperimen & 60,87 & 82,50 & 0,55 & Sedang \\
\hline & & & & \\
\hline
\end{tabular}

Berdasarkan tabel 7, maka menunjukan peningkatan hasil belajar di kelas ekserimen dengan kriteria sedang yaitu 0,55 , sedangkan kelas kontrol berada pada kriteria rendah yaitu 0,29.

\section{Analisis Deskriptif Hasil Observasi Penerapan Model Course Review Horay}

Hasil analisis observasi penerapan model CRH pada muatan pelajaran IPA disajikan pada tabel 8 berikut.

Tabel 8 Hasil Observasi Penerapan Model Course Review Horay

\begin{tabular}{cccccc}
\hline \multirow{3}{*}{ Kelas } & \multicolumn{4}{c}{ Persentase Pertemuan ke- } \\
\cline { 2 - 5 } & 1 & 2 & 3 & 4 & Rata- \\
\hline
\end{tabular}

Eksperimen $72 \% \quad 81 \% \quad 89 \% \quad 94 \% \quad 84 \%$

Berdasarkan tabel 8 menunjukan terdapat peningkatan aktivitas siswa pada proses pembelajaran yang menerapkan model Course Review Horay dikelas eksperimen dari pertemuan pertama sampai pertemuan keempat.

\section{PEMBAHASAN}

Model Course Review Horay berbantuan media konkret lebih efektif terhadap hasil belajar IPA. Hasil posttest menunjukan bahwa hasil belajar kelas eksperimen lebih besar dibandingkan kelas 
kontrol. Pembelajaran model CRH memiliki suasana belajar yang produktif dengan saling berinteraksi dan bertukar pikiran. Proses tersebut membantu siswa untuk berkembang dan berpikir kritis dalam memahami konsep melalui diskusi kelompok dan pengujian pemahaman (Mediatati, 2016:114). Pemberian materi oleh guru yang dibantu dengan media konkret yang ada di sekitar lingkungan membuat pembelajaran mejadi lebih bermakna karena siswa dapat menerapkannya dalam kehidupan sehari-hari. Pemahaman materi dilakukan melalui mengkonstruksi pengetahuan pada pengalaman yang dialaminya.

Pembelajaran pada model ini menekankan cara belajar dan mengajar dengan berkompetisi yang diadakan oleh guru untuk menguji pemahaman siswa. Model Course Review Horay bukan hanya belajar mengenai akademik dan ketrampilan, akan tetapi juga melatih siswa dalam mencapai tujuan pembelajaran sehingga terjadinya suatu hubungan sosial yang dapat berpengaruh pada prestasi akademik. Kondisi ini berkontribusi dalam membantu siswa yang mengalami kesulitan belajar, sehingga akhirnya siswa mencapai hasil yang maksimal (Ritonga dan Tanjung, dalam Suheria, dkk. 2019: 67). Keefektifan model pembelajaran kooperatif tipe Course Review Horay berbantuan media konkret menunjukan adanya hasil belajar yang meningkat pada kelas eksperimen yang lebih tinggi dibanding kelas kontrol.

Penelitian terdahulu yang mendukung, yaitu penelitian yang dilakukan Ni Luh Gita Sri Antari, Kt. Pudjawan, \& I Md. Citra Wibawa (2019) dengan judul Pengaruh Model Pembelajaran Kooperatif Tipe Course Review Horay Berbantuan Media Gambar Terhadap Hasil Belajar IPA. Penelitian ini menunjukkan bahwa terdapat perbedaan yang signifikan antara hasil belajar siswa di kelas eksperimen dan kelas kontrol. Penelitian lain yang dilakukan oleh Pramadita, Anjar A., dkk (2013) berjudul "Keefektifan Model Pembelajaran Course Review Horay terhadap Hasil Belajar dan Minat Belajar Siswa". Penelitian ini menunjukan bahwa minat dan rata-rata hasil belajar siswa yang menggunakan model pembelajaran $\mathrm{CRH}$ lebih tinggi daripada model pembelajaran ekspositori.

Penelitian yang dilakukan oleh Bety Ratih

Meganingtyas, Retno Winarni, \& Tri Murwaningsih (2018) berjudul "The Effect of Using Course Review Horay and Talking Stick Learning Methods Towards Social Science Learning Result Reviewed From Learning Interest". Penelitian ini menunjukan bahwa model course review horay lebih efektif untuk meningkatkan hasil belajar siswa. Penelitian oleh Tjokorda, I Gede Margunayasa, \& Nyoman Kusmariyatni (2019) yang berjudul "Pengaruh Model Pembelajaran Kooperatif Tipe Course Review Horay Bermediakan Audio Visual Terhadap Hasil Belajar IPA". Hasil penelitian ini menunjukan bahwa hasil belajar siswa kelas eksperimen dengan model Course Review Horay berbantuan media audio visual lebih tinggi dibandingkankan dengan kelas control yang menggunakan model pembelajaran konvensional. Hal ini berdasarkan perolehan skor rata-rata hasil belajar IPA kelas eksperimen adalah 23,58 dengan kategori sangat tinggi, sedangkan skor rata-rata dengan model pembelajaran konvensional adalah 15,23 berada pada kategori sedang.

Penelitian lain yang mendukung yaitu penelitian oleh Gull F., Shehzad S. (2015) "Effect of Cooeperative Learning on Students Academic Achievement". Hasil penelitian menunjukan bahwa terdapat perbedaan yang signifikan antara skor kelompok eksperimen sebelum dan sesudah intervensi $(p=0,000)$. Hal tersebut disimpulkan bahwa proses pembelajaran kooperatif mempunyai dampak positif terhadap prestasi akademik dan hasil belajar sangat baik. Penelitian yang dilakukan oleh Made Indrieta Sari, dkk (2017) dengan judul "Pengaruh Model Pembelajaran Course Review Horay Terhadap Aktivitas dan Hasil Belajar Kognitif IPA Siswa Kelas V". Hasil uji hipotesis menunjukkan aktivitas siswa kelas eksperimen lebih tinggi dibandingkan kelas kontrol dan hasil belajar rata-rata kelas eksperimen meningkat. Penelitian lain yang mendukung yaitu penelitian oleh Tshewang Rabgay (2017) yang berjudul "The Effect of Using Cooperative Learning Method on Tenth Grade Students' Learning Achievement and Attitude towards Biology". Penelitian ini menunjukan bahwa model pembelajaran kooperatif lebih tinggi dibandingkan dengan model ceramah pada bidang biologi terhadap prestasi akademik.

Berdasarkan teori tersebut, hasil penelitian menunjukkan model Course Review Horay berbantuan media konkret lebih efektif diterapkan pada pembelajaran. Hasil ini sesuai dengan hipotesis penelitian ini bahwa rata-rata hasil belajar IPA menggunakan model Course Review Horay berbantuan media konkret lebih besar daripada rata-rata hasil belajar IPA menggunakan model konvensional. Hasil penelitian ini dapat menjadi referensi dalam menguji keefektifan model Course Review Horay.

\section{SIMPULAN}

Berdasarkan hasil penelitian dan pembahasan maka dapat disimpulkan bahwa Model Course Review Horay berbantuan media konkret lebih efektif dibandingkan dengan model pembelajaran konvensional terhadap hasil belajar IPA kelas V SDN Gugus Wolter Monginsidi Kabupaten Kendal. Hasil uji t-test menunjukan $t_{\text {hitung }}>t_{\text {tabel }}$ yaitu $(3,142>1,997)$, artinya hasil belajar kelas eksperimen lebih besar daripada hasil belajar kelas kontrol. Hal ini didukung oleh hasil uji $\mathrm{N}$-gain kelas eksperimen sebesar 0,55 yang berkategori sedang, dan kelas kontrol sebesar 0,29 yang berkategori rendah.

\section{UCAPAN TERIMA KASIH}

Penulis mengucapkan terima kasih kepada Desi Wulandari, S.Pd, M.Pd. selaku dosen pembimbing, Drs. A. Busyairi, M.Ag. selaku Mitra Bestari I, Dr. Sri Sulistyorini, M.Pd. selaku Mitra Bestari II, Farid Ahmadi, S. Kom., M. Kom., Ph. D., selaku penyunting bahasa Inggris yang telah 
memberikan bimbingan dan masukan dalam menyusun manuskrip ini.

\section{DAFTAR PUSTAKA}

Antari, N. L., dkk. 2019. Pengaruh Model Pembelajaran Kooperatif Tipe Course Review Horay Berbantuan Media Gambar Terhadap Hasil Belajar IPA. International Journal of Elementary Education. 3(2): 121. (P-ISSN: 2579-7158 E-ISSN: 2549-6050).

Arsyad, Azhar. 2014. Media Pembelajaran. Jakarta: PT Rajagrafindo Persada.

Carin, A.A \& Sund, R. B. 1993. Teaching Science Throught Discovery. Seventh Editon. Charles Merry Publishing Co. Ohio.

Dewi P, Tjokorda Istri Mirah Satya dkk. 2019. Pengaruh Model Pembelajaran Kooperatif Tipe Course Review Horay Bermediakan Audio Visual Terhadap Hasil Belajar IPA. International Journal of Elementary Education, 3(2):146. (P-ISSN: 2579-7158 E-ISSN: 2549-6050).

Faradita, Meirza N. 2017. Pengaruh Model Pembelajaran Kooperatif Tipe Course Review Horay Terhadap Motivasi Belajar Siswa Mata Pelajaran IPA di Sekolah Dasar. Elementary School Education Journal, 1(2b): 191. (P-ISSN: 2581-1800 E-ISSN: 2597-4122

Gull F., \& Shehzad S. 2015 "Effect of Cooeperative Learning on Students Academic Achievement". Journal of Education and Learning, 9(3). ( pp . 246-255).

Huda, Miftahul. 2014. Model-model Pengajaran dan Pembelajaran. Yogyakarta: Pustaka Belajar.

Joyce, B. \& Weil, M. 1996. Model of Teaching. Needham Heights : A. Simon \& Schuster Company.

Laguador, Jake M. 2014. Cooperative Learning Approach in an Outcomes Based Enviroment. Internasional Jurnal of Social Sciences, Art and Humanities, 2 (2): $46 . \quad$ Philippines University.

Mediatati, Nani, dkk. 2016. Penggunaan Model Pembelajaran Course Review Horay dengan media Flipchart sebagai Upaya Meningkatkan Hasil Belajar PKN. Jurnal
Ilmiah Sekolah Dasar, 1(2). (ISSN:113121).

Meganingtyas, Betty R.,dkk. 2018. The Effect of Using Course Review Horay and Talking Stick Learning Methods Towards Social Science Learning Result Reviewed From Learning Interest. International Journal of Educational Research Review, 4(2): 194.

Peraturan Indonesia. 2016. Peraturan Menteri Pendidikan dan Kebudayaan Nomor 23 tahun 2016 tentang Standar Penilaian Pendidikan Sekolah Dasar dan Menengah 2018. Peraturan Menteri Pendidikan

dan Kebudayaan Nomor 37 tahun 2018 tentang Kompetensi Inti dan Kompetensi Dasar Pelajaran pada Kurikulum 2013 pada Pendidikan Dasar dan Pendidikan Menengah. Sekretariat Negeri Republik Indonesia: Jakarta.

Pramadita, Anjar A., dkk. 2013. Keefektifan Model Pembelajaran Course Review Horay terhadap Hasil Belajar dan Minat Belajar Siswa. Unnes Journal of Mathematics Education, 2(2): 37. (ISSN 2252-6927).

Rabgay, T. 2017. The Effect of Using Cooperative Learning Method on Tenth Grade Students' Learning Achievement and Attitude towards Biology. International Journal of Instruction, 11 (2): 274-276. (e-ISSN: 1308-1470).

Sari, Made Indrieta, dkk. 2017. Pengaruh Model Pembelajaran Course Review Horay Terhadap Aktivitas dan Hasil Belajar Kognitif IPA Siswa Kelas V. e-Journal PGSD Universitas Pendidikan Ganesha, 5(2):9.

Sugiyono. 2016. Metode Penelitian Pendidikan Pendekatan Kuantitatif, Kualitatif, dan $R \& D$. Bandung: Alfabeta.

Suheria, dkk. 2019. Penerapan Model Pembelajaran Kooperatife Tipe Course Review Horay (CRH) dan Jigsaw terhadap Hasil Belajar Siswa Kelas X Pada Materi Redoks SMA Negeri 9 Palu. J. Akademika. Kim. 8(2): 67. (ISSN 23026030).

TIMSS. 2015. International Science Achievement. Boston: Boston Collage. 